\title{
THE MEANING OF AUTHORITY RELATION OF CENTRAL GOVERNMENT AND LOCAL GOVERNMENT \\ IN THE LAND SECTOR ACCORDING TO THE 1945 CONSTITUTION \\ OF THE REPUBLIC OF INDONESIA
}

\author{
Nurus Zaman \\ Faculty of Law University of Trunojoyo Madura \\ Email : Zamany_02@yahoo.co.id
}

\begin{abstract}
In this study, there are two (2) issues examined. First, how the Central Government and Local Government gained authority in the land sector. Second, how the meaning of the relationship of authority of the Central Government and Local Government in the area of land according to the 1945 Constitution, This study uses normative legal research. The results of research are: First, the authority of the Central Government in the land sector is the inherent nature of authority, because as the sole power in a unitary state. In the development of central government authority derived from attributive authority and Local Government authorities in the land sector sourced from attributive authority and discretionary. Second, the meaning of the relationship of authority between the central government and the regional government in the land sector as: (a) the relationship of subordination; (B) the relationship of supervision; and (c) the relationship of responsibility in achieving the objectives of the State.
\end{abstract}

Keywords: Relations Authority, Central and Local Government, Land

\section{A. INTRODUCTION}

In the viewpoint of constitutional law, the state is an organization of power, and it is the working order of the means of state equipment which is a wholeness, whose work describes the relationship and the division of duties and obligations between each of the state's means of procurement to achieve a certain purpose (Soehino, 1999: 149). Each country has certain goals, what is the goal for a country or in which direction a state organization is addressed is an important issue, because with this purpose that guides how the state is organized and controlled and how the life of the people is arranged according to that purpose (I Gde Pantja Astawa dan Suprin Na'a, 2009: 45). In general the purpose of the country is to organize the welfare and happiness of its 
people, or to organize a just and prosperous society (Soehino, 1999: 149). Achieving the country's goals through the organs within the country, that is the Government.

One of the important objectives of the State is regulated in the provisions of Article 33 Paragraph (3) of the 1945 Constitution, which is essentially to create the prosperity of the people, through the right of state control over the earth, water and natural resources contained therein. The right to exploit the State has 5 (five) forms of authority possessed by the State, namely: (1) the function of policy making; (2) regulatory functions; (3) the maintenance function; (4) management functions; And (5) supervisory function.

The five functions of the State regarding the right to control the State over the provisions of Article 33 Paragraph (3) of the 1945 Constitution, in the context of a unitary State like Indonesia will hamper the implementation and acceleration of the objectives of the state to be achieved, one of which is to create the welfare and prosperity of all people. Thus, the State requires to disseminate the authority to the Regional Government. According to I Gde Pantja Astawa (I Gde Pantja Astawa, 2012) in addition to the function of surveillance, then the other functions can be given authority to Local Government, in order to achieve the goals of the State becomes more rapid and effective. Authority is the ability to engage in a public legal act or acting capacity provided by applicable law to conduct legal relationships (Marbun S.F, 2005: 153).

The further provisions of the provisions of Article 33 paragraph (3) of the 1945 Constitution are regulated in the provisions of Article 2 of UUPA which states that:

a. On the basis of the provisions of Article 33 Paragraph (3) of the Constitution and matters referred to in article 1, earth, water and space, including natural resources contained therein at the highest level controlled by the state, as the whole power organization people. 
b. The right to control of the country referred to in paragraph (1) of this article authorizes to:

1. to organize and administer the designation, use, inventory and maintenance of the earth, water and space;

2. to determine and regulate the legal relations between persons and the earth, water and space;

3. determine and regulate the legal relationships between persons and legal acts concerning the earth, water and space.

c. The authority derived from the right of control of the country in paragraph (2) of this article is used to achieve the greatest prosperity of the people, in the sense of happiness, prosperity and independence in the society and the legal state of Indonesia is sovereign, just and prosperous.

d. The right of control of such a State may be authorized to the Swatantra and customary law communities, as necessary and not contrary to the national interest, in accordance with the provisions of the Government Regulation.

\section{B. PROBLEM STATEMENT}

Based on the above background, the problems in this research are as follows: First, how the Central Government and Local Government obtain authority in the land sector?. Second, what is the meaning of the relation of authority between Central Government and Regional Government in the land sector according to the 1945 Constitution?

\section{RESEARCH METHODS}

This study uses normative legal research. Normative research is a legal research that includes research on legal principles, research on legal systematics, research on the level of legal synchronization, legal history research, and comparative law studies (Soerjono Soekanto, 1981: 51). Legal material consists of primary legal materials and secondary legal materials. Primary legal material namely the 1945 Constitution, especially the 
provisions of Article 1 paragraph (1) of the 1945 Constitution, Article 18A of the 1945 Constitution, Article 33 Paragraph (3) of the 1945 Constitution, Article 2 number 23 of 2014 about Regional Government, and Article 2 of Law Number 5 of 1960 on the Basic Regulations of Agrarian Principles. Secondary legal materials in the form of books, journals and previous research results in the form of thesis, dissertation related to the problems and opinions of experts who have relevance to the issues discussed. While the approach used there are 2 (two) namely the approach of legislation and conceptual approach.

The technique of collecting legal materials used in this research is literature study that is by studying the positive law regulation related to the issues discussed, and the books relevant to the problems, form of: the 1945 Constitution and Law Number 23 of 2014 on Regional Government. Furthermore, the collected material will be analyzed descriptively qualitative.

\section{RESEARCH RESULTS AND DISCUSSION}

\section{D.1. Source of Authority of Central Government and Local Government In The Land Sector}

The mechanism of division of authority is defined as the handover of government affairs and this is related to the approach used. The Government of Indonesia uses the approach of general competence or open end arrangement, ie the affairs undertaken by central government is limitative and the rest becomes the authority of local government (Josep Mario Monteiro, 2016: 39).

The unitary state, the concept of state governing the power relations (gezagsverhounding) between the Central Government and the Regional Government (Pimpinan MPR dan Tim Kerja Sosialisasi MPR Periode 20092014, 2012: 167). Central Government as the forerunner of the Regional Government automatically has inherent authority. However, in its development, as a State the law of such authority is regulated through prevailing laws and regulations, in which the authority of the Central 
Government has attributive authority. Similarly, autonomous regions as independent government units have attributive authority, in addition to delegative authority as a consequence of subsystems of the Center (Melisa Fitria Dini, 2014: 97).

In achieving the state's goal of mutual prosperity, the Government has a double position which must be exercised at the same time. Both sorts of Government positions relate to each other. Firstly, on the one hand the Government is domiciled as a competent authority to make rules that must be obeyed by the community so that public order and peace can be realized in reality. Secondly, on the other hand the Government is based as a public service (public servant) who is in charge of administering, organizing and serving all the affairs and interests of the community (Hotma P. Sibuea, 2010: 42).

Based on Article 18 Paragraph (2) of the 1945 Constitution states: Provincial, district and municipal governments shall regulate and manage their own governmental affairs according to the principle of autonomy and assistance tasks. While based on the provisions of Article 33 paragraph (3) of the 1945 Constitution states: Earth, water and natural resources contained therein are controlled by the State and used for the greatest prosperity of the people.

\section{D.2. Relation of authority between the Central Government and the}

\section{Regional Government in the Land Sector}

\section{Sub-ordination relationships}

The State is an organization within a territory that has the highest authority that is legitimate and obeyed by its people. Power is the ability of a person or another group, in accordance with the wishes of the perpetrators (Miriam Budiardjo, 2008: 17-18). The 1945 Constitution stipulates that the state of Indonesia is a unitary state. According to C.F. Strong (Miriam Budiardjo, 2008: 269-270), unitary state is a state where the highest legislative authority is centered within a national or central 
legislative body. Power lies with the Central Government and not to the Regional Government.

The central government can surrender some of its power to the regions based on autonomous rights (a unitary state with a decentralized system), but at the last stage the highest power remains in the hands of the Central Government. So the sovereignty, both sovereignty to the sovereign and the outer sovereignty, lies entirely with the Central Government, and thus the unity of the unitary state is that its sovereignty is not divided, or in other words the power of the Central Government is not restricted, since the constitution of the unitary state does not recognize the legislative body Other than the central legislature. C.F. Strong further concludes that there are two absolute features in the unitary state, firstly, the supremacy of the Central People's Legislative Assembly; Second, no other institutions sovereign. CF. Strong says (C.F. Strong, 1966: 84):

"...the essence of a unitary state is that the sovereignty is undivided, or, in order words, that the powers of the central government are unrestricted, for the constitution of unitary state does not admit of any other law-making body than the central one."

According to Solly Lubis, in a unitary state there is the principle that all state affairs can not be shared between the central government and the local government in such a way that the affairs of the state within the unitary state remain a unanimity and That the highest power holders in the country are the Central Government (Solly Lubis, 2003: 61).

The principle of power sharing in a unitary state is: Firstly, power and / or authority is basically the property of the Central Government, the regions are given the right and obligation to administer and carry out some of the delegated or assigned government authorities, here the process of surrender or delegation of authority. Second, the Central Government and the Regional Government still have a command line and hierarchical relations. Local Government as sub-ordination of the Central Government, 
but the relationship is not to intervene and dictate the Regional Government in various respects. Third, the power or authority transferred or transferred to the regions under certain conditions, where the regions are not able to run properly, the authority delegated and submitted can be withdrawn to the Central Government as the owner of such power or authority. Based on the concept of a unitary state, regardless of the method used by both ultraveres and general competence, the existence of the role of the Central Government is still needed to oversee and control the overall implementation of government (Agus Salim Andi Gadjong, 2013: 87). Therefore, the authority possessed by the Regional Government, both the attributive and delegative authority in the land sector, such authority shall not exceed the basic principles applicable in the context of a unitary state. Daniel Bell in "The World in 2013" suggests that the national state is too small to organize and deal with enormous problems, but too great to organize and take care of too much problems (Eko Prasojo, 2006: 3). The logical consequence of this point of view is the handover of some powers to sub-national and local units. Therefore, governance and governance will constantly change periodically in both a federal and a unstructured state or a unified state.

In the opinion of Ateng Syafrudin, that the background of the unitary state embraces the decentralization system is the size of the territory, the increasing number of tasks that must be administered by the Central Government, the existence of regional differences with each other that are unruly and uniformly managed by the Central Government. Furthermore Ateng Syafrudin added, in the constitution each state gives the authority of the Government of the State to one Government, that is to the Central Government, because the implementation of all the interests of the right both from the center and from the region is actually an obligation of the Central Government (Ateng Syafrudin, 1993: 193-194).

According to M. Solly Lubis, the Government in the region is an integral part of the political system and national development so that the 
political lines and legislation regarding government in this area should be consistent with the insights and the national political system. The benefits of appearance and disclosure of the relationship between the development of political lines and legislation on governance in the area of Indonesia are as follows (M. Solly Lubi, 2008: 155-157):

1. It can be seen how far the central government as a unitary state government in its position and responsibility implements a line of political policy and national law in the territory of the united state;

2. It can be seen, however, that the extent to which the government and government in the region are subordinated to the central government of the unitary state, has the authority and responsibility in the implementation of the national political and legal concepts concerning regional government in its territory within the framework of the concept of political unity, social unity and culture , Economic unity, and security defense unity.

The relationship between the Central Government and Regional Government in the 1945 Constitution can be examined from the following matters: (1) concerning the form of state; (2) how the power of government is exercised; (3) how the policy of decentralization, namely the relationship between the Central and Regional. These three components can not be separated from each other, because they are an important principle in governmental administration. First, the state of Indonesia is a unitary state, the provision of Article 1 paragraph (1) of the 1945 Constitution of RI. The main characteristic of the unitary state form is the highest sovereignty in the hands of the Central Government. Similarly, the power of legislators is in the hands of the House of Representatives of the Republic of Indonesia (Miriam Budiardjo, 2008: 69).

Second, the power of government run by the President, based on the provisions of Article 4 paragraph (1) of the 1945 Constitution. As a consequence of the form of a unitary state, the President thus becomes the 
executive power of government as a bestuur that has administrative power in running the wheel of government (state in bewehing). Government as bestuurzorg (which includes autonomy) may establish administrative procedures relating to the implementation of the Government. Third, the policy of decentralization, namely the relationship between the Central and Regional. The amendment of the 1945 Constitution clearly formulated the relationship between the Central and Regional Governments with the principle of decentralization in response to regional demands that threatened dis-integration of the nation. This assertion as contained in Article 18 of the 1945 Constitution, according to Bagir Manan is the right answer to the threat of disintegration of the nation (Bagir Manan, 2003: 57). Article 18A of the 1945 Constitution states:

(1) The authority relationship between the central government and provincial, district and municipal governments, or between provinces and districts and municipalities, is regulated by taking into account the specificity and diversity of the regions.

(2) The financial, public service, utilization of natural resources and other resources between the central government and regional governments shall be regulated and implemented fairly and in accordance with law.

The provisions of Article 18A Paragraph (1) above, particularly related to the relation of authority in the land sector can not be separated from the essence of Article 33 Paragraph (3) of the 1945 Constitution. Further regulation mandated by Article 18A Paragraph (1) of the 1945 Constitution shall remain Derived from Article 33 Paragraph (3) of the 1945 Constitution, including the government which is exempted from Article 18A Paragraph (1) of the 1945 Constitution. The specificity and diversity of the regions excluded in the article indicates that the article framers appreciate the facts that exist, Areas that have historical value (special and special). On the same side the exceptional areas may be different from those not excluded in carrying out its administration. 
Nevertheless, every existing form of government (special, special) local government remains as a sub-system of the administration of a unitary government, it is appropriate and a necessity in every act of government to refer to the rules and legal provisions outlined by The parent government, the Central Government (Saldi Isra, 2016 via http://www.saldiisrak.web.id).

The implementation of decentralization in Indonesia is closely linked to the pattern of authority discharges between the Central Government and the Regional Government. This is because in the implementation of decentralization there are always two important elements, namely the establishment of autonomous regions and the handover of legal authority from the Central Government to the Regional Government to regulate and manage certain parts of government affairs. Visually, the power can be divided in two ways, are (RM. A.B, Kusuma, 2004: 31):

1. Vertically, the division of power by level and in this case is the division of power between several levels of government. Carl J. Friedrich uses the term territorial division of power;

2. Horizontally, the division of power by function. This division shows the differentiation of governmental functions that are legislative, executive and judicial, better known as trias politica or division of power.

Therefore, the consequence of a unitary State of authority possessed by the Regional Government in the land sector originates from the result of the dissipation of authority from the Central Government, especially those originating from the provisions of Article 33 paragraph (3) of the 1945 Constitution. The dissemination of authority in the land sector, in order to speed up Destination Country. However, the authority possessed by the Regional Government should be subject to the Governance of the Central Government as a party that gives authority. The administration of government affairs can be categorized as the affairs of the broad autonomy 
government, when it has fulfilled several caveats as follows, First, the affairs of the local household are determined categorically and the development is regulated in certain ways as well. Second, if the supervision and supervision system is done in such a way that the autonomous region loses its independence to freely determine the means of regulating and managing its regional household. Third, the financial system between the central and regional governments that raises things like the limitations of native finance capability that will limit the space for regional autonomy (Bagir Manan, 2002: 38). There is a view that the relationship between the Central Government and Local Government is the relationship between the organization, not the relationship of intraorganization. The relationship between the autonomous regions is an equal relationship, not hierarchical (HAW. Widjaja, 2002: 93).

Meanwhile, based on the provisions of Article 9 of Law Number 23 of 2014 on Regional Government, divides 3 (three) levels of government affairs, namely: First, government affairs consisting of government affairs entirely the authority of the Government. Second, government affairs shared among levels and / or government structure (central government, provincial and district / city government). Third, the government affairs which are the authority of the President as head of government.

\section{Relationship Control.}

The principle of the relationship between the Central Government and the Regional Government in the form of a unitary state there is a clear and clear distinction compared to the principle of relationship between the Central Government and the Regional Government in the federal state. In the opinion of Austin Ranny, that in a unitary state of the Central Government has supremacy, it is very different from the state of the union which under certain conditions the state has freedom of interference with the Central Government (Rondinelli and Cheema, 1983: 18). 
There are two criteria to distinguish between a federal state and a unitary state based on positive law. First, states in federal state ties have a pouvoir constituant, that is, the authority to form the Constitution itself and the authority to regulate its own organizational form within the framework of the federal constitution, whereas the unity of the subnational government within the unitary state has no pouvoir constituant and its organization in general Determined by lawmakers in the Central Government. Secondly, within a federal state, the authority of the federal legislature is specified in detail in the federal constitution. While in a unitary state, the authority of the central legislature is regulated in general, While the empowering authority in the metrical meaning of the subnational (regional) government depends on the central legislature (Agus Salim Gadjong, 2013: 88).

In a unitary state, there are two ways to connect between the Central Government and the Regional Government. Firstly, it is called centralization, where all the functions, duties, functions and authority of government administration are in the central government whose implementation with deconcentrally. Secondly, it is known as decentralization, which Rondinelli and Cheema interpreted as the delivery of planning, decision-making or governmental authority of the Central Government to its organizational sections, local government units, semiautonomy, local government or non-governmental organizations (Austin Ranney, 1962: 59).

According to Samuel Humes, the relationship between the Central Government and Local Government is determined in its supervisory system. Based on this supervisory system formed the governance of government relations within a country. Humes Samuel explains that the system of oversight of the Local Government is based on two dimensions: (a) control hierarchy, hierarchical supervision and (b) functional control, functional supervision. Humes Samuel explains the two dimensions are as follows (Humes IV. Samuel, 1991: 4-7): 
One is the extent to which hierarchical control is essentially either interorganizational or intraorganizational. Second is the extent to which such control is focused in a single agency or spread among many functional or specialized hierarchies

Hierarchical supervision is a spectrum of surveillance patterns ranging from interorganizational, inter-organizational, to intraorganization. Functional oversight is the supervision of the spectrum from whether the oversight is done by the functional base agency or done holistically (ministry of interior) by the Government. Supervision carried out by the functional agency means supervision of the Local Government conducted by sector agents, especially on the affairs that became the field of duty. Supervision is done holistically means supervision of Local Government is done by General Government Agent (general purpose administration / agency) or known as representative of Central Government, for example by Governor.

Inter organizational or inter-organizational supervisory pattern means supervision over the course of local government is carried out by organizations in the area itself. Intra organizational supervision is supervision conducted by the Central Government because the Regional Government is part of the Central Government so that its supervision is nothing but internal control (Bhenyamin Hoessein, 2005: 38). In the doctrine known as preventive supervision, where the supervision of this form is divided into two kinds (I Wayan Parsa, 2003; 114-115): First, supervision is executed before the lower-level government takes or determines a decision. For example, a statement of no objection from higher-level government. Second, supervision is done after the lower level Government takes a decision, but before the decision is in effect and has legal consequences. For example, the endorsement and announcement of the enactment. Unitary state with decentralized system, the position of Local Government is lower than the Central Government (C.F. Strong, 1966: 80). 
Any form of authority in the land sector owned by the Regional Government in a unitary state does not mean a freedom to exercise such authority without supervision. To ensure that freedom remains in the bonds of a unitary state, it is necessary to supervise the Central Government. According to Obsorne M. Reynolds, Jr., the supervisory relationship between the Central Government and Local Government can also be seen in the prevailing system of government in the United States. Initially the inherent home role doctrine or first-line house writing doctrine developed in Michigan in 1871 received recognition by other local governments such as Indiana, Lowa, and Kentucky. But at the present time the doctrine that limits the role of the Central Government to oversee the Local Government in carrying out the affairs of the original nature has been rejected by other Local Government so that still merely doctrine (Obsorne M. Reynolds, 1982: 68). The rejection of the doctrine is based on the consideration that the city or local government remains part of the Central Government, so that in conflict situations the Central provisions apply. Another consideration is that the implementation of central government oversight of the Local Government is essentially a penalty or consequence that must be accepted by the Local Government. All Local Government in the United States is an object of supervision by the Central Government unless the state constitution stipulates otherwise (Obsorne M. Reynolds, 1982: 75).

The position of Regional Government according to the 1945 Constitution, the Regional Government is a part and form of government structure within a unitary state which is not eenheidsstaat nature. The Central Government is the personification of the state power form which has sovereignty, which is the authority to establish and apply the law in its jurisdiction (C.F. Strong, 1966: 7).

While Wolhoff uses a political approach, namely systems and functions approach in the perspective of internal sovereignty of a country. The unitary state in principle is all power held by the Central Government. 
Thus the central regulation that determines the form, the composition of the autonomous regional government, the kinds and the extent of its power to regulate and manage its own household according to its own initiative, and / or organize and manage central matters within its territory according to the instructions of the Central Government, Where the Central Government keeps control of the oversight power over the autonomous regions (G.J. Wolhoff, 1955: 97):

In the relationship between the Central Government and the Local Government, the monitoring system will also determine the autonomy of the autonomous unit. To avoid so as not to undermine autonomy, the monitoring system is specifically determined both in terms of scope and procedures. More and more intensive supervision narrows the regional self-consciousness. The narrower the independence of the more limited autonomy. On the other hand there can be no autonomy that completely negates control (Bagir Manan, 2003: 39). Implementation of governance based on law is characteristic of state law, where according to Prins and Sholten that state law is not seen from its form, but its content, that is how power is executed and who supervise (Diana Halim Koentjoro, 2004: 36).

Based on the provisions of Law Number 23 of 2014 amendment of Law Number 32 Of 2004 supervision of governance can not be separated from the supervision of the Central Government. The supervisory system in Law 23 of 2014 is regulated in Article 7 and Article 8. Article 7 states, the Central Government conducts guidance and supervision on the implementation of government affairs by the regions. Furthermore Article 8 of Law Number 23 of 2014 states: coaching and supervision by the Central Government on the implementation of government affairs by the Provincial Region implemented by the Minister / head of non-ministerial government institutions. Guidance and supervision by the Central Government on the administration of government affairs by Regencies / municipalities is carried out by the governor as the representative of the 
Central Government and national guidance and supervision is coordinated by the Minister.

Based on the description of the concept of supervision above, it can be drawn a conclusion that the implementation of authority in the land sector owned by the Regional Government is done by the higher government. This is not to eliminate the original concept of a unitary state, that power is essentially single. However, the controls under the jurisdiction of the Government shall be restricted and in accordance with the laws and regulations, it is intended that the monitoring shall not be arbitrary. Supervision by the Central Government to the Government under it is important to undertake and serve as an element of obligation as a result of the occurrence of the dissemination of authority in order to accelerate the realization of state objectives. On the other hand, the Regional Government must accept any supervision by the Central Government, especially the authority in the land sector.

This supervisory authority relationship is a structural / hierarchical oversight. On the other hand, these structural / hierarchical relationships should not inhibit the principles of autonomy. This is the essence of the concept of a unitary state, that is always the supervision of the central government to the Government under it. Even based on the Minister of Home Affairs Regulation Number 1 Of 2010 on Information System for Supervision of Implementation of Local Government Nationally, in its consideration mentioned, in order to improve efficiency and effectiveness of implementation of supervision and supervision of local government administration need to utilize information technology. Thus, the authority of land originating from whatever is owned by the Regional Government remains an inherent right of the supervision of the Central Government.

\section{Responsibility Relationship In Achieving State Goals}

The main purpose of the state is in the preamble to the 1945 Constitution, specifically stated in the fourth paragraph which states: 
"Later than that to form an Indonesian state government that protects the whole Indonesian nation and the whole of Indonesia's blood sphere and to promote the common prosperity, educate the life of the nation, and participate in implementing a world order based on freedom, eternal peace and social justice ..........".

The essence of the provision contains the philosophical value of the responsibility of the state to implement it. The founding fathers, with an awareness of the responsibility and great desire to build the nation as well as possible, must be a spirit for the next generation of nations. The pluralistic, pluralistic, pluralistic, diverse country of Indonesia, and the vast territory, etc., must be built on the joints of the state's objectives. The form of a unitary state as a state design demands the nation's founding thinkers to formulate how the mule's state goal will be more quickly realized.

In accelerating the achievement of the objectives of the state in particular to create the welfare and prosperity of the people as outlined in the preamble and Article 33 paragraph (3) of the 1945 Constitution, requires various patterns and models of how such a thing becomes a reality not just as a mere discourse and desire. One of the ways in achieving prosperity and prosperity is the formulation of Article 18 of the 1945 Constitution which states the following paragraph: (1) The unitary state of the Republic of Indonesia is divided into provinces and provinces divided into districts and municipalities, each province, Local government regulated by law. (2) provincial, regency and municipal governments shall administer and manage their own governmental affairs according to the principle of autonomy and co-administration.

Based on the above provisions, actually the division of existing areas in the value and predicted will further accelerate the purpose of the State, considering the Unitary State of the Republic of Indonesia is very broad and diverse. After the dissemination of power to the regions of responsibility to achieve the goals of the state is not only the responsibility of the Central Government, but also the responsibility of the Regional Government. The Regional Government as a part of the Central 
Government also has an inseparable authority with the objectives of Article 33 Paragraph (3) of the 1945 Constitution. But the authority is regulated in detail in legislation, because the substance of the principle of legality is the authority (Juniarso Ridwan dan Ahmad Sodik Sudrajat, 2012: 136). In authority, there are two main elements, namely rights and obligations, both of which are inherent in every legal subject. The authority possessed by the government organizers is an obligation to achieve the objectives of the state, with the authority of the objectives will be more easily achieved. On the other hand the essence of the principle of the unitary state which becomes the spirit of the nation and the state is maintained. The responsibility for achieving the state's objectives is not only charged to the Central Government, but also part of the responsibilities of the Regional Government.

The relationship between the Central Government and the Regional Government should be established and based on the ideology and legal basis of the state, thus, the relationship built will strengthen the sense of unity and unity of the existing regions. Such a way implies that between the Central Government and the Regional Government both have the responsibility in implementing and achieving the State's goal of creating the prosperity of the people through the provision of Article 33 Paragraph (3) of the 1945 Constitution. In every country in the world, the authority to perform public service functions is distributed Centrally and locally. Centrally, the authority has been divided based on the activities of various ministries in the capital. At the local level, the authority is divided on the basis of existing territories in various regional governments throughout the country. Both systems are interlinked and complementary, even though in practice overlap and compete with each other (Sarundajang, 2002: 28).

In the consideration of Law 23 of 2014 on Regional Government states: In the framework of the implementation of local government in accordance with the mandate of the 1945 Constitution, the regional governments that regulate and manage their own governmental affairs 
according to the principle of autonomy and the task of determining, directed to accelerate the realization of the welfare of society through improvement, service, empowerment, And participation of the community, and enhancement of regional competitiveness by taking into account the principles of democracy, equity, justice, privilege and specificity of a region within the system of the Unitary State of the Republic of Indonesia.

In achieving the state's goal of mutual prosperity, the Government has a double position which must be exercised at the same time. Both sorts of Government positions relate to each other. Firstly, on the one hand the Government is domiciled as a competent authority to make rules that must be obeyed by the community so that public order and peace can be realized in reality. Secondly, on the other hand the Government is located as a public service (public servant) who is in charge of administering, organizing and serving all the affairs and interests of the community (Hotma P. Sibuea, 2010: 42).

\section{E. CLOSING}

Based on the discussion as described above, the conclusions generated in this study are as follows: First, Central Government Authority is initially an inherent authority, as a single power within a unitary state. In its development, the authority of Central Government comes from the attributive authority. While the authority of the Regional Government in the land sector comes from the attributive authority and delegative authority. Second, the meaning of authority relationship between the Central Government and Regional Government in the land sector is interpreted: (a) subordination relationship; (b) supervision relationship; And (c) the responsibility relationship in achieving the objectives of the State.

\section{BIBLIOGRAPHY:}

\section{Books:}


Budiardjo, Miriam, 2008, Dasar-dasar Ilmu Politik Edisi Revisi (Fundamentals of Political Science), Jakarta: Gramedia Pustaka Utama

Gadjong, Agus Salim Andi, 2013, Hukum Pemda: Otonomi Daerah dan Implikasinya (Local Government Law: Regional Autonomy and Its Implications), Yogyakarta: Total Media

Koentjoro, Diana Halim Koentjoro, 2004, Hukum Administrasi Negara (Administrative Law), Bogor: Ghalia Indonesia

Lubis, M. Solly, 2008, Hukum Tata Negara (Constitutional Law), Bandung: Mandar Maju,

Kusuma. 2004, Lahirnya Undang-Undang Dasar 1945 (The Birth of The 1945 Constitution of The Republic of Indonesia), Jakarta: UI Press

Manan, Bagir, 2002, Menyongsong Otonomi Daerah (Welcoming Regional Autonomy), Yogyakarta: Pusat Studi Hukum Fakultas Hukum UII

Marbun, 2005, Peradilan Admministrasi Negara dan Upaya Administrasi di Indonesia (The State Administrative and Administrative Court in Indonesia), Yogyakarta: UII Press

Monteiro, Josep Mario, 2016, Pemahaman Dasar Hukum Pemerintahan Daerah, Konsep, Kewenangan, Organisasi, Desa, Produk Hukum Desa, dan Pemerintah Daerah (Basic Understanding of Local Government Law: Concepts, Authority, Organization, Village, and Local Government), Yogyakarta: Buku Seru

Ranney, Austin, 1962, The Governing of Men, New York: Holt Rinerhart and Winston

Reynolds, Obsorne M, 1982, Handbook of Lokal Government, USA: Hornbook Series, Paul Minn, West Puslishing Co

Ridwan, Juniarso and Ahmad Sodik Sudrajat, 2012, Hukum Administrasi Negara dan Kebijakan Pelayanan Publik (Law of the State Administration and Public Service Policy), Bandung: Nuansa.

Rondinelli and Cheema, 1983, Decentralization ang development, Policy Implementation in Developing Countries, Beverly Hills: Sage Publication

Samuel, Humes Samuel, 1991, Local Governance and National Power, London: IULA

Sarundajang, 2002, Pemerintahan Daerah Di Berbagai Negara (Local Government In Various Countries), Jakarta, Pustaka Sinar Harapan,

Sibuea, Hotma P, 2010, Asas Negara Hukum, Peraturan Kebijakan \& Asas-asas Umum Pemerintahan yang Baik (Legal Country Principles, Good Governance Policy Rules and Principles), Jakarta: Erlangga

Soehino, 1999, Ilmu Negara edisi ketiga (Science State), Yogyakarta: Liberty

Strong, C.F, 1966, Modern Political Constitution, London: Sidgwick \& Jackson Limited

Soekanto, Soerjono, 1981, Pengantar Penelitian Hukum (Introduction to The Legal Research), Jakarta: UI Press

Suprin Na'a, I Gde Pantja Astawa, 2009, Memahami Ilmu Negara (Understanding the State Science), Bandung: Refika Aditama 
Syafrudin, Ateng Syafrudin, 1993, Pengaturan Koordinasi Pemerintahan Di Daerah.Bandung (Governance Coordination Arrangements in Bandung), Citra Aditya Bakti

Tanya, Bernard L, 2011, Politik Hukum Agenda Kepentingan Bersama (Legal Politics of The Common Interest Agenda), Yogyakarta: Genta Publishing

Widjaja, HAW, 2002, Otonomi Daerah dan Daerah Otonom (Autonomous Region and Autonomous Region), Jakarta: Raja Grafindo Persada

Wolhoff, J, 1955, Pengantar Ilmu Hukum Tata Negara Republik Indonesia (Introduction to the Constitutional Law of the republic of Indonesia). Jakarta: Timun Mas

\section{Regulations :}

The 1945 Constitution of The Republic of Indonesia

Law Number 23 of 2014 on The Local Government (State Gazette of The Republic of Indonesia Number 244 of 2014)

Law Number 5 of 1960 on the Agrarian Law (State Gazette of The Republic of Indonesia Number 104 of 1960)

\section{Article/Journals/Speech :}

Dini, Melisa Fitria. 2014. Urgensi Pengawasan Preventif Terhadap Qanun Number 3 Tahun 2013 tentang Bendera dan Lambang Aceh. Yogyakarta. Jurnal Hukum Ius Quia Iustum, Vol 21, Number 1

Hoessein, Bhenyamin Hoessein. 2005. (et.al), Naskah Akademik Tata Hubungan Kewenangan Pemerintah Pusat dan Daerah. Jakarta. Pusat Kajian Pembangunan Administrasi Daerah dan Kota

Lubis, Solly dalam I Wayan Parsa. 2003. Pengawasan Pemerintah (Pusat) Dalam Penyelenggaraan Pemerintahan Daerah. Surabaya. Disertasi Program Pascasarjana Universitas Airlangga

Parsa, I Wayan. 2003. "Pengawasan Pemerintah (Pusat) Dalam Penyelenggaraan Pemerintahan Daerah”. Surabaya. Disertasi Program Pascasarjana Universitas Airlangga

Pimpinan MPR dan Tim Kerja Sosialisasi MPR Periode 2009-2014. 2012. Empat Pilar Berbangsa dan Bernegara. Jakarta. Sekretariat Jenderal MPR RI

Prasojo, Eko. 2006. Konstruksi Ulang Hubungan Pemerintah Pusat dan Pemerintah Daerah Di Indonesia: Antara Sentripetalisme dan Sentrifugalisme.Depok. Pidato Pengukuhan Sebagai Guru Besar Tetap FISIP UI

\section{Website :}

Isra, Saldi. 2016. Pembagian Kewenangan Pusat-Daerah Dalam UndangUndang Nomor 11 Tahun 2006 tentang Pemerintahan Aceh. Di Akses tanggal 19 Agustus 2016 melalui http://www.saldiisrak.web.id. 